Hydrology and Earth System Sciences, 8(6), 1016-1029 (2004) C EGU

\title{
The hydrological significance of mountains: from regional to global scale
}

\author{
Daniel Viviroli and Rolf Weingartner \\ Department of Geography, University of Berne, Switzerland, Hallerstrasse 12, CH-3012 Berne, Switzerland
}

Email for corresponding author: viviroli@giub.unibe.ch

\begin{abstract}
Mountain regions supply a large share of the world's population with fresh water. Quantification of the hydrological significance of mountains, however, is subject to great uncertainty. Instead of focusing on global averages in advance, the present analysis follows a catchment-based approach using discharge data provided by the Global Runoff Data Centre (GRDC). The River Rhine originating in the European Alps is chosen as a first study area, revealing the hydrological relationship between mountainous and lowland regions in a well-documented area. Following the findings from this analysis, different aspects of runoff characteristics for a total of 22 case-study river basins world-wide have been investigated and compared, for a global view. The view has been extended through aspects of climate and human use of mountain runoff. The particular hydrological characteristics of mountain areas are characterised by disproportionately large discharges. In humid areas, mountains supply up to $20-50 \%$ of total discharge while in arid areas, mountains contribute from $50-90 \%$ of total discharge, with extremes of over $95 \%$. The overall assessment of the hydrological significance of mountain areas reveals that the world's major 'water towers' are found in arid or semi-arid zones where they provide essential fresh water for a significant proportion of a quickly growing global population.
\end{abstract}

Keywords: mountain hydrology, global comparative assessment, runoff, water resources, sustainability, Rhine River, European Alps

\section{Introduction}

Most of the rivers on this planet have their sources in mountain regions. The discharge which builds up there is transported via river systems to lower lying areas where it is often used for irrigation and, thus, for producing food. Although mountain regions, defined as areas over 1000 metres above sea level, comprise only $27 \%$ of the Earth's continental surface (Ives et al., 1997), they supply a far greater part of the world's population with water. For this reason, they are often referred to as natural 'water towers'.

It is generally agreed that mountain regions are of significant hydrological importance and a clear distinction should be made between global mean and regional values. Estimates for the proportion of mountain to global total discharge differ from 32\% (Meybeck et al., 2001) to 40$60 \%$ (Bandyopadhyay et al., 1997). Regionally, mountain discharges can represent as much as $95 \%$ of the total flow in a catchment (Liniger et al., 1998). Dürr (2003) recently proposed a GIS-based approach to discern 'small' and 'big water towers' in space, based on the relatively higher specific discharge of mountain areas which function as natural reservoirs.

Nikkanen et al. (2004) noted that regional and temporal aspects are of special importance when considering water availability; this is still often neglected in individual studies. Therefore, a case-study approach has been chosen which leads to a comparative, global assessment; being based on mean monthly discharge records from the Global Runoff Data Centre (GRDC, 2003), it also resolves seasonal particularities.

After considering the definition of mountains, the hydrological importance of the European Alps is examined to assess the influence of mountains on the hydrology of a well-monitored area, followed by a comparative assessment 
of 22 selected macro-scale river basins world-wide. Experience from the well-studied Alps is, thereby, transferred to a scale where fewer and less reliable data are available. Aspects of climate and of human use of mountain runoff are evaluated separately, followed by conclusions and an outlook.

\section{Defining mountains}

As Ives et al. (1997) noted aptly, the quest for a globally applicable definition of mountains is "to chase a chimera". Agreed criteria for defining mountains are generally relative altitude and slope which, in turn, lead to strong environmental gradients and unstable environments. These conditions also lead to marginality in terms of human settlement due to steepness, poor soils, cool temperatures and inaccessibility. Although it seems undisputed that elevations above $2500 \mathrm{~m}$ a.s.l. are mountainous, areas at lower elevations are more difficult to distinguish on a global scale since the effects of altitude vary with local conditions such as the size of the mountain mass, the situation within the global circulation system, continentality and latitude. Additionally, the definition must consider relative topography which may be crucial because of the orographic effect. This led to the definition of Kapos et al. (2000) which adds criteria concerning local elevation range and slope to the primary criterion of altitude, starting at $300 \mathrm{~m}$ a.s.l. Although helping global comparisons, these criteria need to be adjusted individually if a specific region is in focus (e.g. Browne et al., 2004). For the European Alps, the lowest altitude class (300-1000 m a. s. 1.) had to be excluded and the resulting pattern had to be smoothed to produce a reasonable definition (Viviroli and Weingartner, 2004). Meybeck et al. (2001) presented a very sophisticated catalogue of 15 relief classes based on a relief roughness indicator and altitude zones. While it is able to define low mountains and hills, it may not appeal to a pragmatic user due to its high distinctive ability and complexity. A very interesting procedure was recently proposed by Browne et al. (2004) who, amongst other methods, used geographic names for tracing South Africa's mountains. While surprisingly appealing patterns were produced for other mountain ranges world-wide, the approach seems to fail in regions where the underlying database is too sparse or varied, such as in the Himalayas.

Regarding the European Alps, three additional definitions are of interest:

- For their water balance study, Baumgartner et al. (1983) drew an orographical border by tracing the foot of the Alps as far as it was apparent, omitting hydrographical aspects. This alpine zone was then divided hierarchically into different climate and mountain regions. Being explicitly subjective, it is meaningful for the Alps but not necessarily comparable with other mountain regions. According to this definition, the Alps enclose an area of $195500 \mathrm{~km}^{2}$, as compared to an area of $\sim 140000$ $\mathrm{km}^{2}$ for the adapted Kapos et al. (2002) definition described above (Viviroli and Weingartner, 2004).

- According to the criteria of Bätzing (1993), the Alps are characterised somewhat subjectively by geomorphological and geological particularities which for instance also result in difficulties in cultivation. Defined thus, the Alps enclose an area of $181500 \mathrm{~km}^{2}$ and 11 million inhabitants. The same philosophy was applied for the Alpine Convention which defines the alpine area legally at municipality level; due to some inconsistencies, the figures are slightly higher (area $191300 \mathrm{~km}^{2}$, 13 million inhabitants).

- The alpine arc according to 'Europe 2000+' (in CIPRA, 2003 ) considers, primarily, interactions with the adjacent European environs, thus stressing factors such as tourism, traffic and energy as well as air quality and water. With an area of $450000 \mathrm{~km}^{2}$ and 79 million inhabitants, it defines an alpine area more than twice as large as those given by the delineations above. While this definition is interesting in terms of delineating a functional area which may be of importance when considering water resources management, for the purposes of devising hydrological distinctions, it seems to be far too wide.

The delineation and extent of mountains in Europe were recently discussed in detail by Price, Lysenko and Gloersen (2004).

From a hydrological point of view, a mountain definition using regime variability suggests itself. The balancing influence of snow and glacier control on runoff can be detected clearly in the hydrograph through more stable monthly patterns; mountains could, therefore, be defined in terms of hydrology. For Switzerland, this would assign basins with a mean altitude of $1550 \mathrm{~m}$ a.s.l. or more to the Alps (Weingartner and Aschwanden, 1992). The result is comparable with the adopted version of Kapos et al. (2002) (Viviroli and Weingartner, 2004) and confirms the relative validity of the latter. On a global perspective, however, such a definition would be possible only if extensive gauge data were available.

Hence, there seems to be no universally valid, objective definition of 'mountains'. The problem of all corresponding definitions is that they are based upon criteria found by empirical testing and selected to produce reasonable results. 
Moreover, local conditions differ so widely that a global rule can hardly be applicable. For the present study, a pragmatic approach was taken, since the main task was to assign existing gauge stations to either mountain or lowland areas. Therefore, the borderline between mountains and lowlands was initially set at the 1000 m contour. Deviations upwards and downwards from this separation were then allowed according to local conditions - e. g. despite being situated at generally lower elevations, the River Niger catchment shows significant relative differences in topography in the upstream section.

\section{The River Rhine and the European Alps}

The River Rhine is clearly divided into two different sections: the upper, mountainous section dominated by steep alpine topography and the adjacent lower section of low mountain ranges, hills and plains. The distinction is also evident in terms of hydrology as the seasonal discharge pattern changes from a marked summer peak towards a more balanced regime with a weak autumn minimum. This reflects a change in the dominant supply from reliable meltwater in summer to more variable precipitation in winter. The alpineregime type discharge from the Swiss section of the Rhine above Lake Constance plus tributary River Aare contributes a long-term average of $34 \%$ to total discharge at Lobith, although the relevant catchment is only $15 \%$ of the total catchment. In the summer months, this discharge is clearly over $50 \%$ when the melting of snow and glacier ice produces high and reliable discharge volumes (Viviroli and Weingartner, 2004).

The mountainous part of the River Rhine plays a distinctive role in the hydrology of the whole basin because of higher precipitation, lower evaporation and, consequently, more effective runoff generation in the Alps as compared to that in the lowlands, especially in the summer months. This is illustrated with water balance figures which were drawn from an HBV-type conceptual model (e.g. Bergström, 1995) run by the Federal Institute of Hydrology in Koblenz. Figure 1 shows the resulting water balance components for two sub-catchments of the River Rhine basin; the climatological water balance (precipitation minus evaporation, $\mathrm{P}-\mathrm{ET}$ ) in the Alpine sub-catchment (Felsberg) is markedly higher because of higher precipitation and lower evaporation than that of the Upper Rhine sub-catchment (Karlsruhe) about $550 \mathrm{~km}$ downstream. Together with seasonal storage in winter, this mountain influence predominates between May and August when melting of snow (mainly May and June) and of glacier ice (July and August) produces significant runoff. This summer runoff from the Alps arrives downstream at a time of negative water balance, thus compensating for the smaller and even partly negative balance term. Precipitation volumes and the ratio of runoff to precipitation are typically even higher in the Alps; for the Canton of Uri, for example, Schädler and Weingartner (2003) found average precipitation of $2088 \mathrm{~mm}$ for the same period of reference (1961-1990), $1711 \mathrm{~mm}$ runoff and evaporation of only $382 \mathrm{~mm}$, suggesting that $82 \%$ of the precipitation is available for runoff as well as seasonal and long-term storage.

To examine runoff stability and, therefore, another important aspect of mountain hydrology, 76 representative mesoscale catchments in Switzerland were analysed on a long-term basis. The data, comprising gauged runoff series from the Federal Office for Water and Geology, were examined using an annual regime variability measure $R$. For a single year $j, R_{j}$ is calculated as

$$
R_{j}=\frac{\sum_{i=1}^{12}\left|\left(M Q \cdot P K_{i}\right)-M Q M_{i, j}\right|}{\sum_{i=1}^{12}\left(M Q \cdot P K_{i}\right)}
$$

where $M Q$ is the long-term annual mean of runoff, $P K_{i}$ the
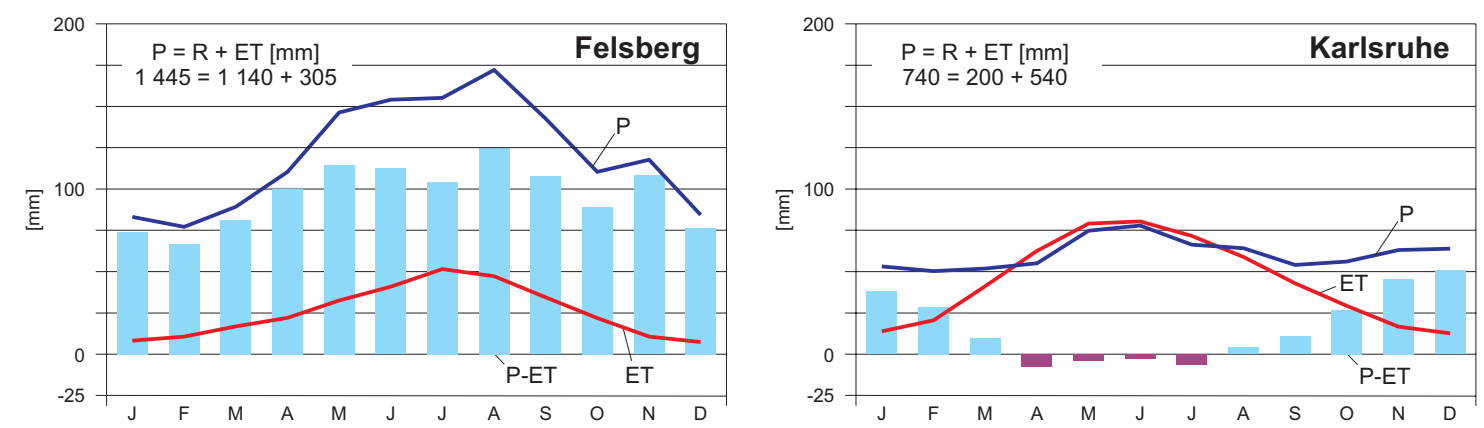

Fig. 1. Mean annual water balance 1961-1990 for two selected sub-catchments of the River Rhine, Felsberg (Alps, mean altitude $1989 \mathrm{~m}$ a.s.l, area $3221 \mathrm{~km}^{2}$ ) and Karlsruhe (Upper Rhine, mean altitude $177 \mathrm{~m}$ a.s.l., area $1944 \mathrm{~km}^{2}$ ). P: Precipitation, R: Runoff, ET: Evaporation, P-ET: climatological water balance. Data source: Federal Institute of Hydrology, Koblenz. 


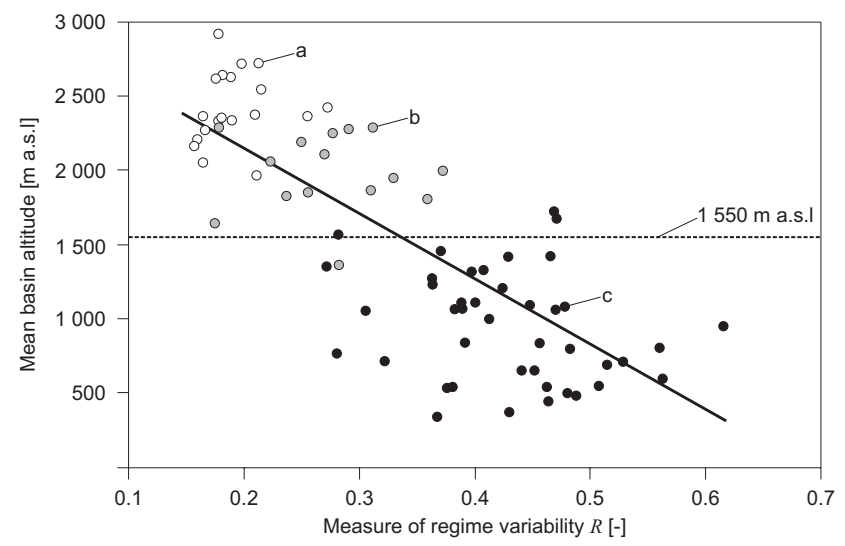

Fig. 2. Runoff variability for 76 representative catchments in Switzerland, compared to mean basin altitude. Regime types under predominant glacial influence (a; glaciaire, glacio-nival) and under predominant snow influence ( $b$; nivo-glaciaire, nival alpin, nival méridional) are distinguished from rain-influenced types (c; pluvial, nivo-pluvial, nival de transition)

long-term Pardé-Coefficient in month $i$ and $M Q M_{i, j}$ the runoff actually observed in month $i$ of year $j$. To obtain the long-term value $R$, the $R_{j}$ values for all gauged years $j$ are averaged; an $R$ of 0 would mean a completely stable regime with monthly means unchanged each year, while increasing $R$ values would signify stronger year-to-year variability in the monthly mean runoff as compared to the long-term average. Plotting $R$ against the mean altitude of the respective basins (Fig. 2) reveals a clear connection which is also statistically significant: with increasing mean altitude, the variability of the runoff regime decreases. The influence of snow (nival regime types above $\sim 1550$ m mean basin altitude according to Weingartner and Aschwanden, 1992) and of glaciers (glacial regime types above $\sim 1900$ m mean basin altitude) becomes decisive, in contrast with the more irregular precipitation processes which occur in lower lying basins.

Extending the view to the European Alps in their entirety, Table 1 examines the four major streams which drain the alpine arc. As observed in the River Rhine, runoff formation is disproportionately high in relation to relative catchment area. With mean contributions of 26 to $53 \%$ of total discharge, the Alps contribute an even higher proportion of total runoff in the summer months, ranging from $36 \%$ in case of the Danube River to $80 \%$ for the Po River. On the whole, disproportionalities of 1.5 to 2.6 in runoff, as compared to relative area, are observed in the Alps. Baumgartner et al. (1983) found that discharge volumes in the Alps are about 3.3 times larger than those for Europe (with precipitation volumes being about 2.2 times larger); although Schädler (1985) reports comparable estimates, this figure may be rather at the upper end of the scale.

\section{Comparative assessment of selected river basins}

\section{METHODS}

In sharp contrast to the large temporal and spatial variability of hydrological processes in mountain areas, the availability of long-term measurement series for higher altitudes is very limited on a global scale. Public access is further hindered in regions of frequent water-scarcity because of the high strategic significance of runoff data, e.g. when international agreements about transboundary rivers are negotiated. Owing to these restrictions, a global comparative assessment in hydrology that is based on gauge data - such as the present work - has to be based upon mean monthly values of runoff and limit its scope to selected regions. Besides, the limitations of runoff data availability apply also to global water balance model approaches which are of increasing importance in water resources studies.

From studies in the more extensively gauged European Alps (Viviroli and Weingartner, 2004) and the River Rhine basin in particular, the basic hydrological patterns of mountains and lowlands can be discerned from long-term monthly runoff data of the main rivers (Viviroli, 2001).The pattern of mean monthly discharge, changes in specific discharge with increasing catchment size and the coefficient of variation of mean monthly discharge have been identified as being of special validity. These strictly hydrological criteria are complemented by comparing prevailing climates

Table 1. Contribution of the Alps to total discharge in the four major alpine streams (Viviroli and Weingartner, 2004).

\begin{tabular}{lccc}
\hline & $\begin{array}{c}\text { Mean contribution of } \\
\text { Alps to total discharge [\%] }\end{array}$ & Share of Alpine region [\%] & $\begin{array}{l}\text { Disproportional influence } \\
\text { of Alpine region }\end{array}$ \\
\hline Rhine & 34 & 15 & 2.3 \\
Rhone & 41 & 23 & 1.8 \\
Po & 53 & 35 & 1.5 \\
Danube & 26 & 10 & 2.6 \\
\hline
\end{tabular}


and considerating the benefits for the lowland population.

On climatological and topographical criteria, a set of 22 case-study river basins was assembled, including the four major alpine rivers. Care was taken to cover a wide range of climatic zones and the most important mountain ranges, but the inner tropical area was omitted because of the outstanding predominance of tropical rains in lowland hydrographs. Moreover, rivers influenced by major dam storage have been excluded. The most restrictive criterion, however, proved to be the existence of accessible, reliable and representative data, from gauging stations distributed appropriately along the river courses. The interrelation between mountain and lowland discharge was then determined from data from a 'mountain' measuring station situated as close to the regional mountain border according to the criteria described earlier and a 'lowland' gauging station near the river mouth. To assess specific discharge patterns along the rivers, all available stations were used. Regions where no suitably located stations were available had to be excluded from the study.

\section{SPECIFIC DISCHARGE}

A distinct hydrological feature of mountains is the more effective discharge generation compared to the lowlands. To assess this particularity, figures of specific runoff for all case-study basins are compared in Fig. 3. In addition to a typical pattern of decrease in specific runoff from mountains to lowlands (i.e. in downstream direction), intercontinental differences are apparent: the steepest decreases are observed in African basins, suggesting strong contrasts in conditions for runoff formation between mountains and lowlands. This means that the lowlands generate little runoff and, therefore, rely heavily on runoff from the mountains. An exception to the rule includes small increases in the uppermost reaches of the River Niger and in the lower Senegal River; these are thought to be caused by the tropical climate (Fig. 6). Marked decreases are also observed in the Asian catchments except for the Mekong River which shows higher runoff formation in the lowlands and runoff generation from the mountains is only of minor importance. In North and South America, patterns of modest (Columbia, Saskatchewan), strong (Río Negro, São Francisco) and very pronounced (Colorado) decrease in specific runoff are found, along with a clear increase in the case of the Orinoco. In the European basins, the decrease in runoff formation towards the lowlands is rather modest as compared with other continents. Lowland areas contribute significantly to total runoff, although less markedly than mountain areas which remain important for each basin's hydrology. Special cases are the Ebro River where a steep decrease is observed in the dryer lowlands
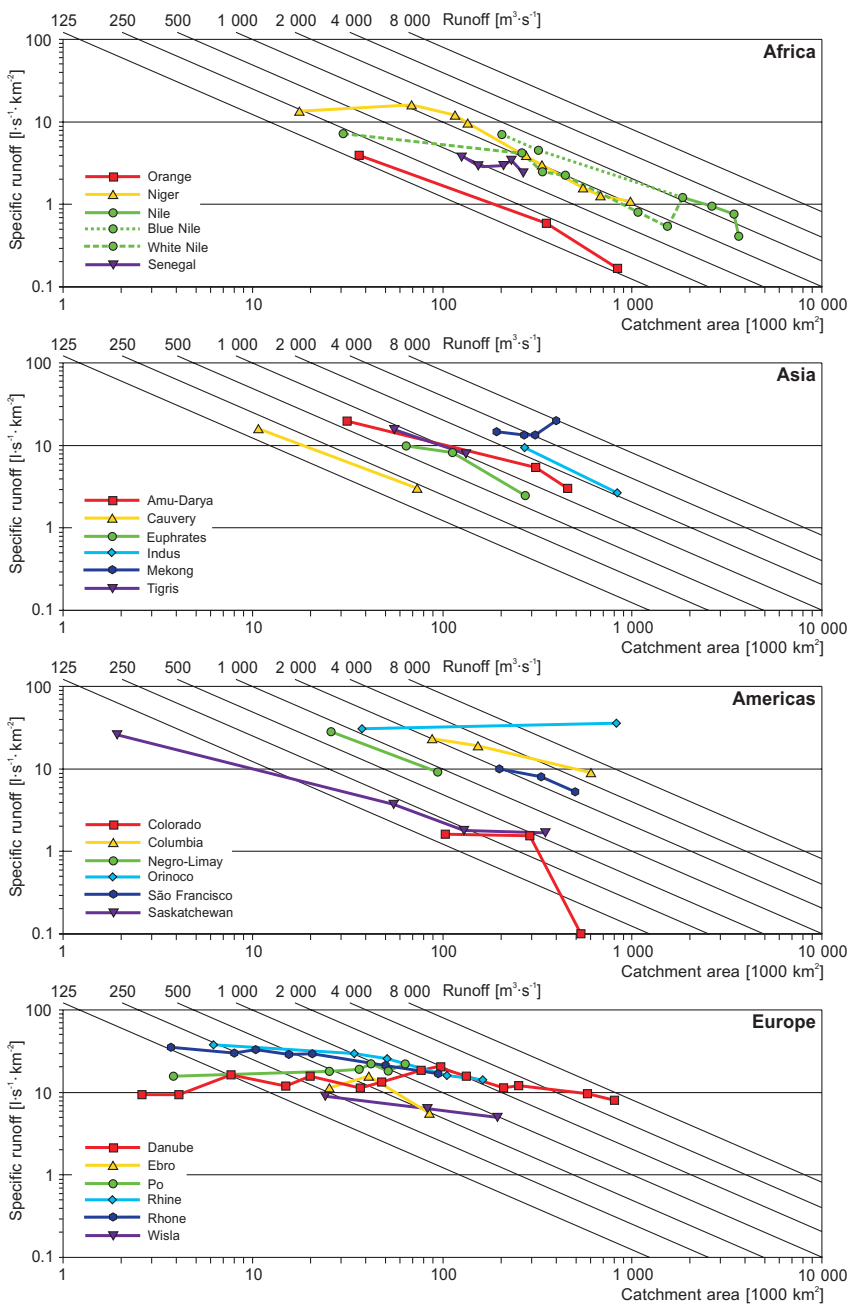

Fig. 3. Comparison of specific runoff for the river basins examined, arranged by continent. The plotted points go from mountain to lowland in moving from left to right.

and the Danube River which shows increases in specific runoff thanks to tributaries originating in the Alps.

\section{DISPROPORTIONALITY OF MOUNTAIN RUNOFF}

To examine the role of mountain runoff in relation to total discharge, the proportion of total discharge generated by mountain areas was compared for the river basins selected, taking into account the relative mountain area. With figures of over $90 \%$, the Orange and Colorado Rivers, the Río Negro, the Amu-Darya and the Nile are by far the most dependent on mountain discharge. In the Euphrates, Tigris, Indus, São Francisco, Senegal, Niger and Cauvery River basins, the rate of mean contribution is lower but still exceeds $50 \%$. In addition, for these basins there are months when mountain discharge represents almost $100 \%$ of total discharge and therefore, seasonally, is of vital importance 
for the lowland areas downstream. For most of the remaining catchments (Ebro, Po, Rhine, Rhone, Saskatchewan, Columbia and Danube), the ratio of area to runoff is typically around 2, i.e. mountains deliver about twice the amount of runoff that could be expected on the basis of their relative area. Exceptions are the Mekong and Orinoco River basins where runoff contributions from the mountains are less than expected.

\section{RUNOFF VARIABILITY}

The compensatory effect of mountain discharge on total discharge was estimated through comparison of year-to-year variability of monthly flows at the selected mountain and lowland stations; the difference signified the reduction in total discharge variability through the influence of the more reliable mountain runoff (Viviroli et al., 2003). This effect generally corresponds with disproportionate mountain runoff contributions; its magnitude is vast for the Colorado and Indus Rivers and is clearly discernible in basins under significant mountain influence. Even for the Orinoco and Mekong Rivers which do not benefit so much from disproportionate volumes of mountain runoff, a clear reduction in runoff variability thanks to mountain influence is observed.

\section{SYNTHESIS}

A quantitative comparison based on the criteria described above (Viviroli et al., 2003) leads to a ranking of the importance of mountains in the river basins examined (Fig. 4). In many cases, mountains are of great importance for the hydrology of the lowlands. Comparing the location of the extremely important 'water towers' to the distribution of arid and semi-arid areas suggests that mountains function as wet islands within comparatively drier areas. This also implies an important role in terms of irrigation for producing food in the lowlands.

\section{Lowland dryness and mountain runoff contribution}

To examine the relation of lowland aridity to mountain water resources, Fig. 5 compares runoff contribution from the mountains to dryness in the lowlands. For this purpose, mean monthly precipitation and temperature according to New et al. (2000) were sampled at the lowland gauging station and the dryness index $i$ after De Martonne (1926) was calculated;

$$
i=N /(T+10)
$$

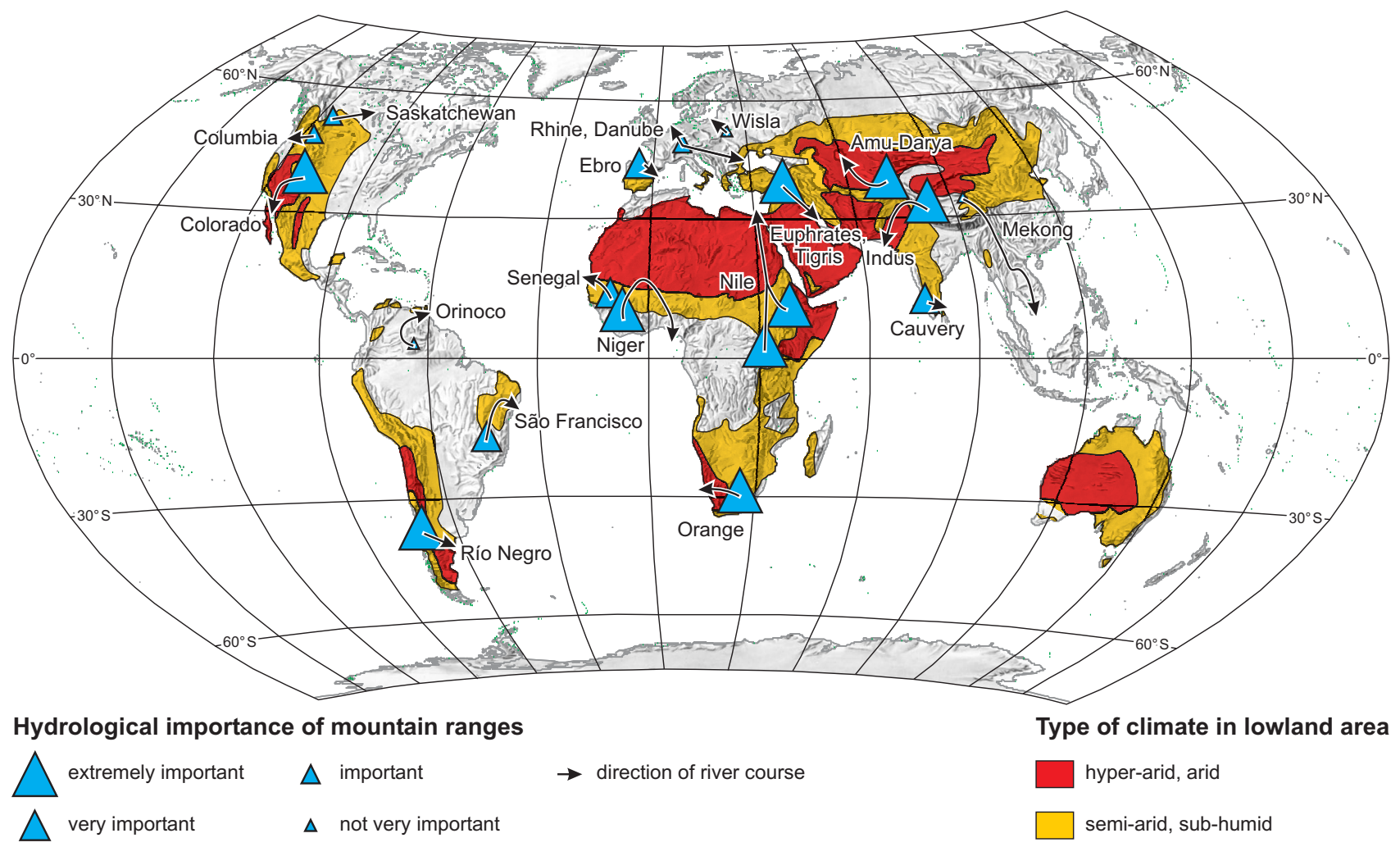

Fig. 4. Hydrological significance of mountain ranges for the river basins considered in this study (Viviroli et al., 2003). 


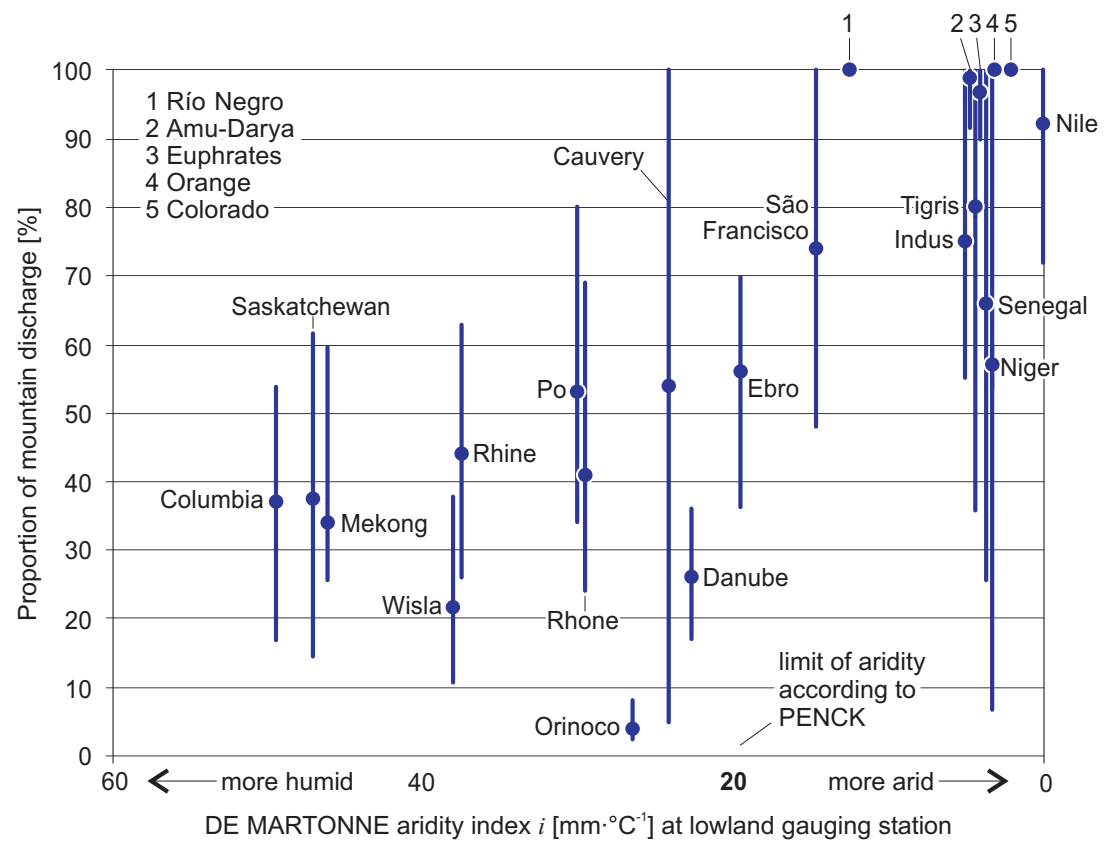

Fig. 5. Comparison of aridity in river basin lowland area against mean annual (dot), maximum and minimum monthly (bar) mountain contribution to total discharge.

$N$ is the annual sum of precipitation and $T$ the mean annual temperature. A greater $i$ means wetter conditions, a smaller one more dry conditions; the aridity limit after Penck (1910) lies at a value of $i=20$. Although physically somewhat questionable because it results in a meaningless dimension, the index seems suitable for probing and comparing lowland dryness in the selected river basins. De Martonne's $i$ is drawn against the mean annual, maximum and minimum monthly contribution from the mountains to total runoff (Fig. 5).

In general, as a result of the reduced runoff term in the water balance downstream, a higher mountain contribution is associated with increasing dryness at the lowland station. As shown in the River Rhine example, the amount of water available for runoff may diminish downstream, an effect which is enhanced under increasingly dry conditions.

- For the catchments outside Penck's zone of aridity $(i>20)$, mountains may contribute as much as $55 \%$ to total runoff. Exceptions from the general pattern are the Orinoco River which is under vast tropical influence and the Wisla River which is dominated largely by moist and cold conditions. On the other hand, the Mekong River would not have been expected to fit the observed trend as its lowland is also dominated by tropical conditions and because it originates in a drier intramontaneous part of the Himalayas. As indicated by the variation bars, mountains may achieve still higher contributions according to the season and may provide important support for river flow in the drier summer months. The high seasonal maximum of mountain runoff in the Cauvery River basin indicates that dependence on mountain water can be stronger; in this case, it is due to the irregularity of the monsoon influence which leads to frequent aridity in single months - a quite decisive feature which is underestimated by De Martonne's index.

- Within Penck's aridity zone, mountain runoff contribution is essential and is more than half of the total runoff for all the catchments studied. The Ebro River is a borderline case and the single exception; all other basins receive almost all of their runoff from the mountains during at least one month of the year. This indicates the high dependence on mountain runoff which in these cases mostly supplies agriculture. This dependence is especially crucial where growth conditions are limited by precipitatiion variability. The importance of the mountain contribution to the Niger River basin seems to be underestimated if the extremely dry conditions in the middle section are considered; this is masked by the river's re-entry into humid tropical climate zones in its lower section (cf. Fig. 6).

As can be seen, the contribution of mountain runoff increases with lowland dryness and becomes crucial when strongly arid conditions occur downstream. This is because mountains usually create more cold and humid climates; 


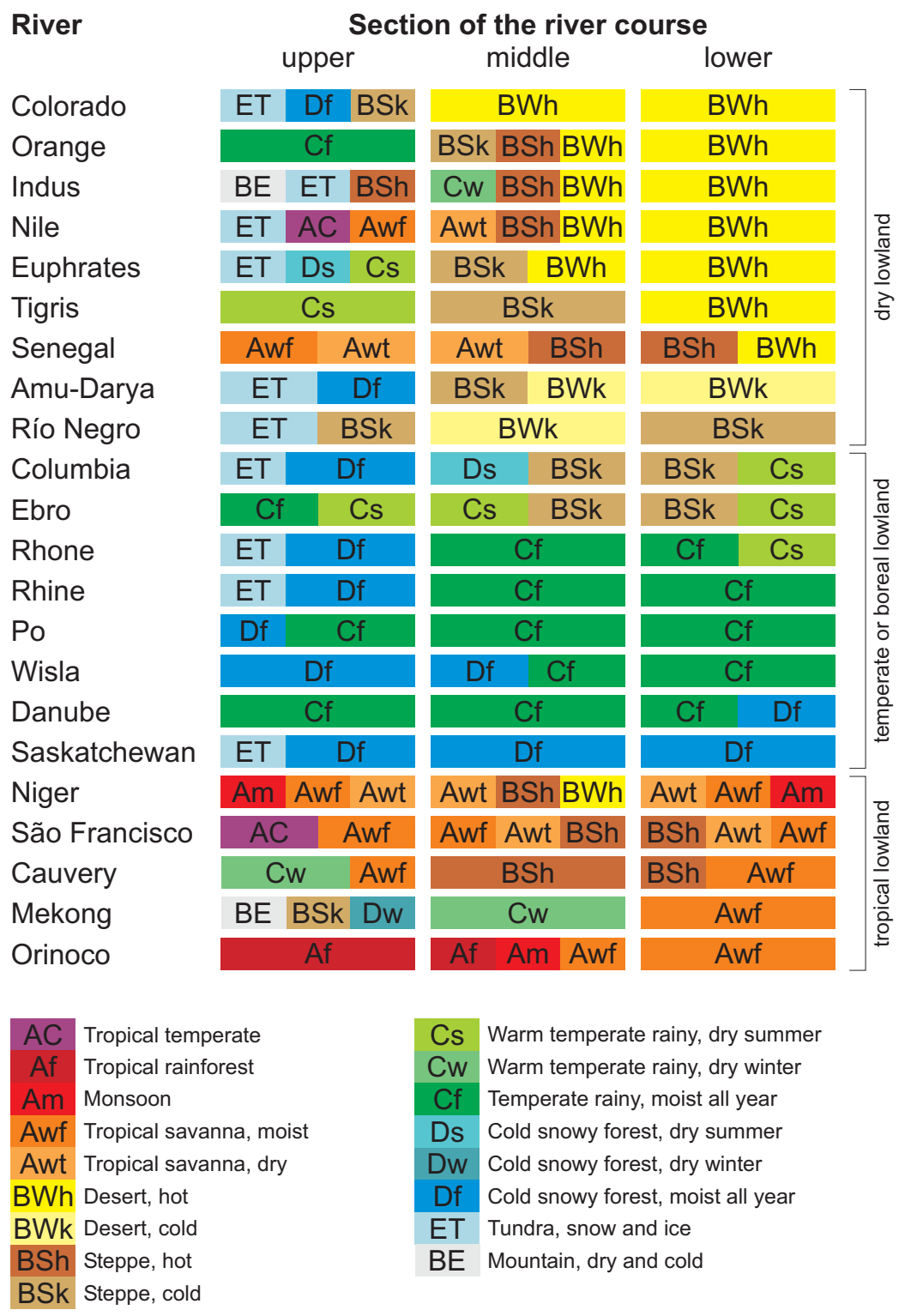

Fig. 6. Distribution of climate zones along the rivers studied, following the Köppen scheme (see Strässer, 1998).

Fig. 6 reveals the climatic differences between mountains and their lowlands. The classification is based on the Köppen scheme (see Strässer, 1998) and was sampled along the rivers using a lightly modified version from Spiess (1994). Köppen's classification divides roughly into tropical (A), dry (B), temperate (C), cold (D) and snow and ice (E) climate types; further distinctions are made according to variations and seasonal patterns in precipitation and temperature. Arranging river basins according to dryness of lowland and middle section reveals three major groups:

- For basins with dry lowland conditions (desert, BWh, or steppe, BS), the upper, mountainous parts mostly experience cooler and wetter climates, thus favouring runoff and seasonal storage in snow and ice. The beneficial effects of mountain climates lessen in large mountain areas, such as in the River Indus basin where runoff originates mainly in the slopes of the Himalayas whereas rain-shadowing increases in the inner zone (dry and cold climate, BE).

- River basins with temperate or cold downstream climates show a transition towards colder and wetter climates in the mountains as well. Where drier, cold steppe conditions (BSk) are observed partly downstream (Ebro, Columbia), mountains are of special importance. Thanks to the rivers, the dry lowland areas are linked 
to the all-year moist cold and temperate sub-types (Df and $\mathrm{Cf}$, respectively) in the mountains.

- Regions dominated by tropical climates downstream show varied upstream conditions; where dryness is observed in the middle sections (e.g. Niger and São Francisco Rivers), the importance of moist tropical conditions in the uplands is enhanced. As to the Cauvery River, the mountains are an important source of runoff for the middle river section; however, the reliability of this runoff is less because of the variability of the monsoon cycle. The Mekong River example shows again that high altitudes need not be disproportionate in terms of runoff formation when aridity and great cold prevail, such as in the inner parts of the Himalayas.

Hence, an important factor in the interaction of upper mountain reaches and lowland areas is the clear difference in their climatic conditions. On the one hand, this is thanks to the uplift of air and the subsequent cooling and condensation generates substantial amounts of rainfall (orographic effect). This is coupled with a reduced evapotranspiration. Through cooler temperatures, the temporary storage of precipitation as snow and ice during the winter half-year becomes important, since it leads to increased discharge during the spring and summer melt period, exactly when demand in the lowlands is greatest. On the whole, precipitation and temperature patterns in the mountains lead to an important contribution to total discharge, which is traceable in figures of specific runoff (cf. Fig. 3).

\section{Mountain water use}

Figure 7 shows two typical examples of human use of mountain runoff, in different climatic zones and for different purposes. On the one hand, the intense use of discharge in the Indus River catchment (Fig. 7, left) by dams, barrages, river links and canals, illustrates the pressure on water
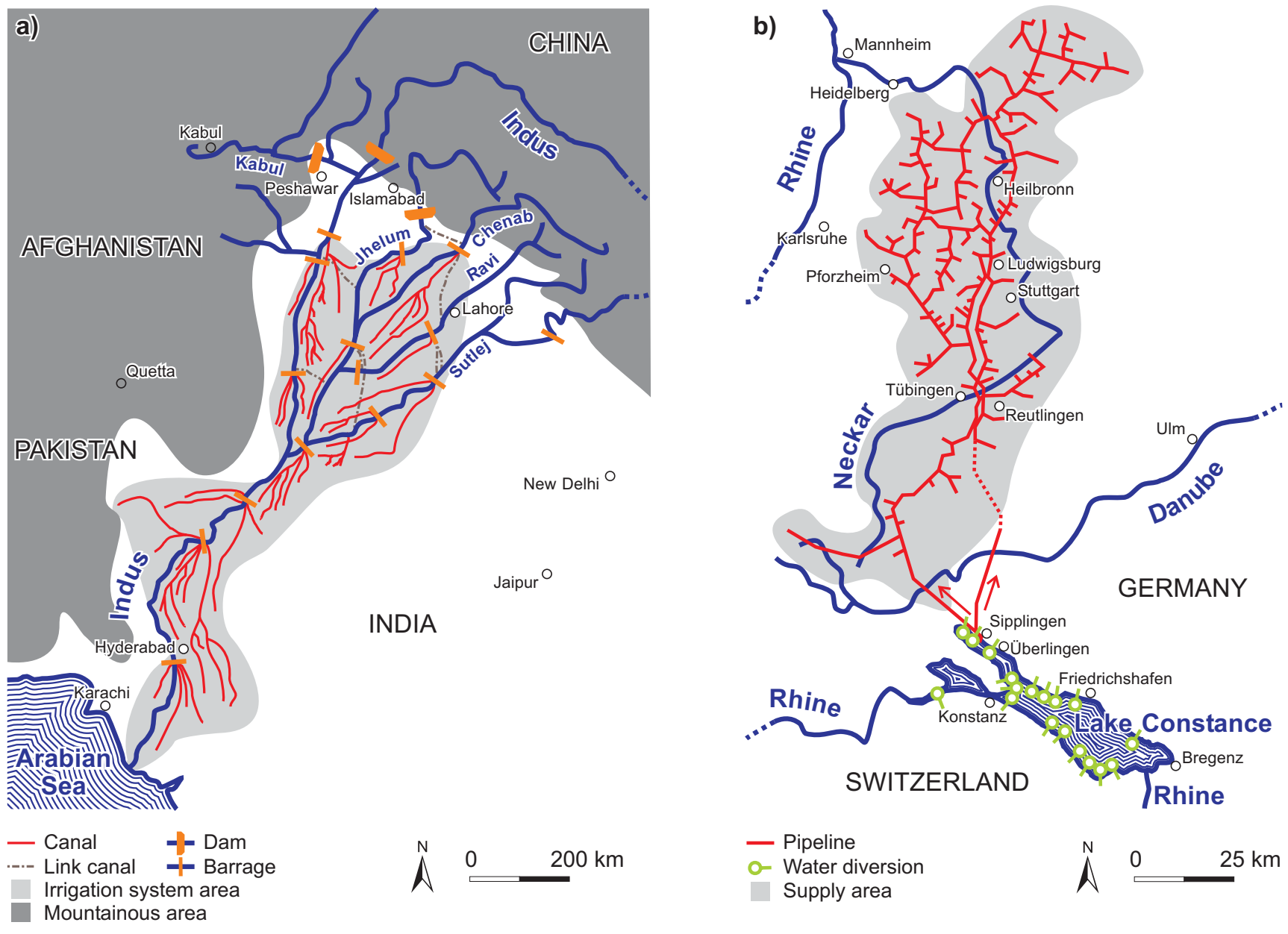

Fig. 7. Examples of mountain discharge use in an arid region (Indus River, a) and a humid region (Rhine River, b); note the different scales. Adapted from Kreutzmann, 1998, Malik and Khan, 1998, Masud, 2001, Vischer, 1994 and ZVBWV, 2002. 
resources in an arid, densely populated region (Kreutzmann, 1998). The steep decrease in specific runoff observed in the Indus River basin may well be due to the high water consumption for irrigation, in contrast to low consumption in the sparsely populated mountainous area. Considering other areas with major irrigation (e.g. Siebert et al., 2002), a similar situation can also be observed in the case of the Amu-Darya. In the Euphrates and Tigris River basins, intense irrigation in the lowlands is even accompanied by growing use upstream; still, the important hydrological role of the mountains is visible downstream. In such areas, lowland consumption for irrigation is decisive - in the respective downstream countries, the portion of annual freshwater withdrawals for agriculture ranges between $92 \%$ (e.g. India, Iraq) and 97\% (Pakistan); the remainder serves households and industry (World Bank, 2001). The essential role of mountain runoff for agriculture is also evident in the Southern Mediterranean (Table 2; Zehnder, 1999): for Egypt, $79 \%$ of total available water (including fossil groundwater, water from desalination, from wastewater recycling and virtual water contained in food imports) originates from external influx from the Nile River. It is mainly this reliable river runoff that allows $100 \%$ of Egypt's cropland to be irrigated, resulting in steadily expanding food production and stable food imports. In contrast, neighbouring Libya does not benefit from a river influx and mines non-renewable fossil groundwater resources to supply its agricultural production, accompanied by increasing food imports. In Tunisia rainfall is unsteady and influx meagre; the resulting year-to-year production fluctuations have to be mitigated by highly variable food imports (Yang and Zehnder, 2002).

In contrast, the water resources of the River Rhine (Fig. 7 , right) are typical of the increasing use in the developed world: water from the Rhine-fed Lake Constance is transferred more than $200 \mathrm{~km}$ to the north for household supply, across the neighbouring river systems of the Danube and Neckar. Increasing water quality problems in downstream areas may raise pressure to use the readily- available, clean mountain water resources; in the case of Lake Constance, the potential service area encloses about 100 million people (Vischer, 1994).

In between the extremes of scarcity and abundance of water supply lie cases such as Nepal. Although possessing abundant per capita water resources $\left(7700 \mathrm{~m}^{3} \cdot \mathrm{a}^{-1} \cdot \mathrm{P}^{-1}\right)$, the supply is highly variable due to the influence of monsoon precipitation and it is difficult to use when large floods occur. Additionally, there is a dry season between October and May. While water use for agriculture accounts for $95 \%$ of total withdrawals, households use only $1 \%$. Despite sufficient supply, Nepal experiences problems with freshwater quality and quantity (Merz et al., 2003); this suggests that better resources management could ease the pressure on water resources.

Depending on the importance of mountain runoff and the water resource it represents, there is a growing potential for conflict (Gleick, 2002). Liebscher (2004) lists nine macroscale transboundary river basins where significant international water conflicts exist already. Of the basins studied here, this applies to the Rivers Amu-Darya, Euphrates, Tigris, Indus and Nile. Also, the potential for conflicts within the next decade was examined; this includes the Rivers Mekong, Orange and Senegal as well as 11 further international river basins. Hence, the majority of international river basins with lowland dryness and significant mountain influence studied here show potential or current water conflicts; the exceptions are the Colorado, Ebro and Niger Rivers. Additionally, within-state conflicts need to be considered as they may lead to serious tensions, as in the Cauvery basin where the water consumption of agriculture and urban areas puts heavy demand on river runoff and strains the relations of two respective Indian states (Imhasly, 2003).

\section{Conclusions}

From the above analysis of case studies it can be concluded that mountains form important and reliable sources of

Table 2. Annually available per-capita water resources 1992-1995 in Egypt, Tunisia and Libya (compiled by Zehnder, 1999)

\begin{tabular}{|c|c|c|c|c|c|c|}
\hline & $\begin{array}{l}\text { EGYPT } \\
{\left[m^{3} \cdot a^{-1} \cdot P^{-1}\right]}\end{array}$ & {$[\%]$} & $\begin{array}{l}\text { TUNISIA } \\
{\left[\mathrm{m}^{3} \cdot a^{-1} \cdot P^{-1}\right]}\end{array}$ & {$[\%]$} & $\begin{array}{l}\text { LIBYA } \\
{\left[\mathrm{m}^{3} \cdot a^{-1} \cdot P^{-1}\right]}\end{array}$ & {$[\%]$} \\
\hline Renewable inland water resources & 28 & 2.5 & 463 & 53.5 & 110 & 7.2 \\
\hline Fossil groundwater & 22 & 2.0 & 40 & 4.6 & 770 & 50.4 \\
\hline River influx from abroad & 880 & 79.4 & 102 & 11.8 & - & - \\
\hline Desalination, wastewater recycling & 4 & 0.4 & 3 & 0.3 & 28 & 1.8 \\
\hline Virtual water (food imports) & 175 & 15.8 & 257 & 29.7 & 619 & 40.5 \\
\hline Total available water resources & 1109 & 100.0 & 865 & 100.0 & 1527 & 100.0 \\
\hline
\end{tabular}


freshwater. This is on the one hand thanks to higher specific runoff, i.e. disproportionately large discharge from mountains resulting from the higher precipitation (orographic effect), coupled with a lower evaporation rate. On the other hand, mountain runoff shows a stable pattern with retarding of discharge through accumulation and storage of winter precipitation as snow and ice and its subsequent melting and runoff in summer. In most of the cases studied, summer runoff variability in the lowlands is reduced, particularly through temporally highly regular melting processes and the long-term compensatory effect of glacier storage in mountains. Since the world's major 'water towers' are located in arid and semi-arid regions, a decrease in specific runoff is observed due to generally drier climate conditions downstream ( $c f$. River Rhine, Fig. 1). This is exacerbated in regions where extensive water withdrawals are made for irrigation. The beneficial stabilising effects of mountain discharges are clearly discernible in the middle and lower sections of the rivers, their extent being influenced by the pattern of climate zones.

In many regions of the world, mountains are marginal areas of human habitation, while the surrounding lowlands favour settlement, agriculture and industry. The very large water use of agriculture emphasises the dependence on mountains for water. There are exceptions in the tropics where mountains ameliorate the climate conditions as compared with the lowlands and are, therefore, preferred for human settlement. In the basins included in this study, discharge from the 'water towers' is of great importance for the lowlands and their inhabitants. Especially in dry climates, water use for irrigation and, thus, food production is essential downstream. Detailed demographic data (CIESIN / IFPRI / WRI, 2000) show that around $70 \%$ of the world's population lives between $30^{\circ}$ North and $30^{\circ}$ South, if the densely populated plains of the Indus and the Huang He are included. The comparative analysis of river basins suggests that some of the most important 'water towers' provide freshwater resources for this zone.

The higher spatial and temporal variability of hydrological processes in mountainous areas faces more sparse gauging networks than in the lowlands. To aggravate the situation, the poor dissemination of recorded information exacerbates the difficulty of assessing mountain water resources. However, the combination of remote sensing and terrestrial observations might help to interpolate between the coarsely distributed ground observations. Also, a research focus on prediction of ungauged water resources in medium-sized and large basins $\left(>10-100 \mathrm{~km}^{2}\right.$ ) is desirable (Lakshmi, 2004). However, ground observations will most likely remain indispensable for all such techniques, which have to be calibrated to real-world data. There is a great need for improving the current ground monitoring of mountain water and to exchange data where recorded. Although it is possible, with due care, to extend knowledge gained in a well-studied mountain region to other regions (Viviroli, 2001), important local patterns may remain hidden in less extensively

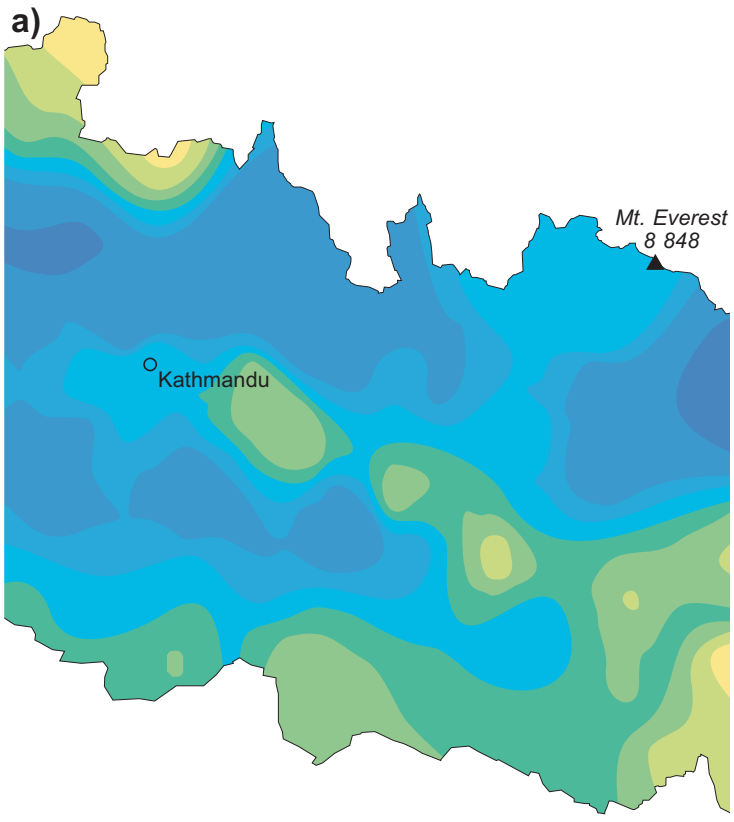

adapted from Climatic and Hydrological Atlas of Nepal, Kathmandu 1996

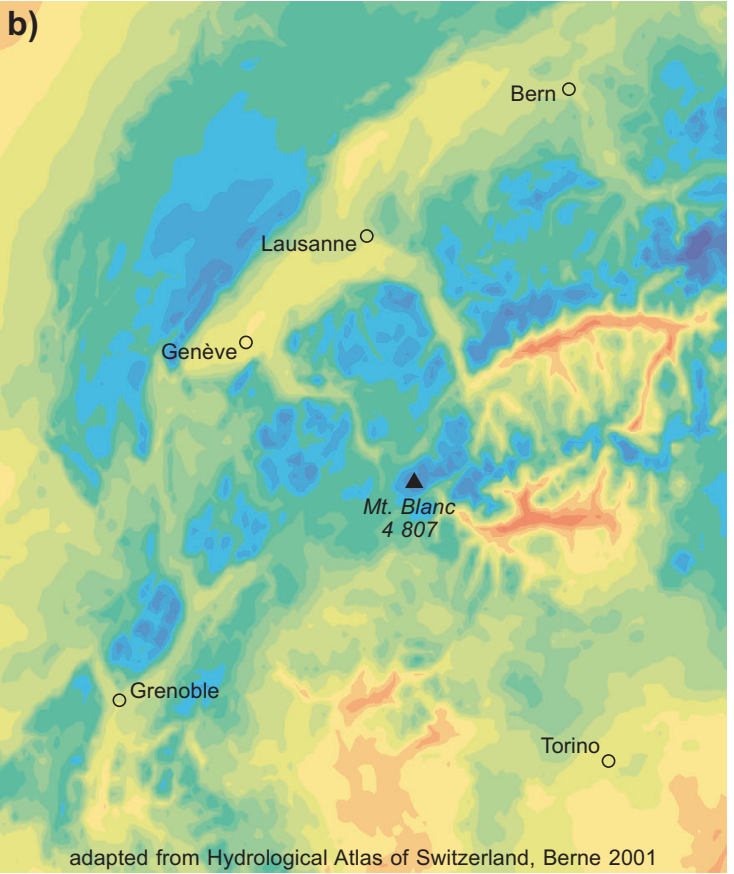

Fig. 8. Comparison of mean annual precipitation maps for the Himalayas (a) and the European Alps (b). Modified from Shrestha et al., 1996 and Schwarb et al., 2001. 
monitored mountain areas. This is illustrated in Fig. 8 which compares the completely different knowledge base in a sparsely (Himalayas, Nepal) with that for a densely (Alps, Europe) monitored area. For the southern slope of the Himalayas, there is knowledge that basic patterns of precipitation increase with altitude (distinctly so in the foothill zone), that the Katmandu valley is drier and that there is a rain-shadowing effect of the high mountain chains towards the north but more detailed climatic features such as are known in the European Alps remain uncertain. Especially when operating meso- or macro-scale hydrological model systems, detailed data from mountainous areas may be of great importance: e.g., for the global model WGHM / WaterGAP (Döll et al., 2003), better results are reported for mountain regions with comparatively denser networks (Schulze and Döll, 2004). It is also proposed to work towards higher temporally and spatially resolved models which would again increase the need for more extensive, qualitatively better data.

\section{Outlook}

Changes in local precipitation, snow cover patterns and glacier storage are likely to affect discharge from mountaindominated territories in terms of timing, volume and variability and will influence runoff characteristics in the lowlands (IPCC, 2001). Catchments which are dominated by snow and, therefore, particularly sensitive to changes, will probably be the most strongly affected by shifts in discharge patterns. With the spatially dense succession of climate zones in mountains, shifts due to changes in environmental conditions will be apparent at the different altitude levels. Hence mountains can also be seen as important indicator regions for global change because they span all climatic regions from north to south and are highly sensitive to changing environmental conditions (Messerli and Hofer, 2003; Messerli et al., 2004).

However, present estimations concerning discharge influenced by climatic change (e.g. Nijssen et al., 2001; Arora and Boer, 2001) conflict with the uncertainty of regional climatic forecasts and with the large scales used in global circulation models (GCMs) which are difficult to downscale to a local level. Research on mountain water resources is further hindered by the difficulties occurring when hydrological models are applied to snow-covered areas and higher altitudes. Although processes of snowmelt are decisive when modelling mountainous areas (Gurtz et al., 2003), they are difficult to incorporate in global-scale approaches. On a local scale, snow accumulation and melt processes are heterogeneous in the mountains because of the rugged topography and because temperature variations are decisive in determining melting or accumulation conditions. Both altitudinal heterogeneity and day-to-day temperature variations have to be incorporated artificially in models operated on the temporal and spatial scales usual today (Schulze and Döll, 2004) and thus uncertainties and errors may result.

Population growth is as important as climate change. In mountain regions, the associated increase in food demand leads to an intensification of land use which, in turn, leads to soil degradation and erosion. The resulting floods and deterioration in water quality, occur mainly on a local and regional level, while the impact in the lower lying areas is minor (Hofer, 1998). However, population growth in critical lowland areas will accentuate pressure on water resources even more due to increased food demand (Vörösmarty et al., 2000; Falkenmark and Widstrand, 1992). Much of this growth is expected to occur between $30^{\circ} \mathrm{N}$ and $30^{\circ} \mathrm{S}$ where mountains supply important water resources. Especially in developing countries, economic development will result in higher meat consumption and therefore $_{2}$ a more waterconsuming nutrition (Zehnder, 2002). These pressures favour the construction of engineering works such as dams and transfers for extensive irrigation, energy production and freshwater supply. With today's engineering skills, even large-scale river water transfers such as India's 'River Link Mega Project' or the 'South-to-North Water Transfer' in China become possible. Changes in runoff regimes in lower lying areas are to be expected (Vörösmarty et al., 1997), affecting water availability for humans and ecosystems in the lowlands.

As a consequence of limited availability and rising demand, more conflicts about water in international river basins are expected, reflecting the importance of rivers linking the more water-abundant mountains with the increasingly thirsty lowlands. Although water should probably not be seen as an exclusive reason for war, it may act as a very powerful and readily available weapon. As Liebscher (2004) notes, it usually takes additional factors to create severe water conflicts, such as unfavourable political structures or ideological differences. Given the frequent cultural and political contrasts between mountain and lowland regions and the uneven distribution of water supply and demand, the potential for conflict between these distinct areas seems to be of special importance. Therefore, the decisive role of mountains has to be taken into account when considering water resources and conflict mitigation.

Although it is difficult to state a specific appeal for the future, the following points seem to be of importance: regionally, it is in the interest of the lowlands to support the economic health of mountain regions and to enable them to use their resources sustainably. Quantity and quality of 
mountain runoff has to be maintained by preserving the integrity of mountain environments and by sustainable use of water resources in the mountains (Messerli et al., 2004). On a larger scale, increased pressure to impound and utilise mountain water resources has to be mitigated by more genuine efforts at negotiation and creation of further multilateral basin riparian organisations; from this point of view, water conflicts may well lead to co-operations. Finally, from the global perspective, it is an imperative to respond to climate change with an effective climate policy. This seems important to prevent fundamental changes in the availability, i.e. in volume and timing, of mountain water resources.

\section{Acknowledgements}

The authors thank Martin Pfaundler and Robert Diezig for their contributions to regime analysis of Switzerland. Peter Krahe (Federal Institute of Hydrology, Koblenz) kindly provided access to model data from the River Rhine. Conference funding support from the Swiss Hydrology and Limnology Society is gratefully acknowledged.

\section{References}

Arora, V.K. and Boer, G.J., 2001. Effects of simulated climate change on the hydrology of major river basins. J. Geophys. Res.-Atmos., 106, 3335-3348.

Bandyopadhyay, J., Kraemer, D., Kattelmann, R. and Kundzewicz, Z.W., 1997. Highland Waters - a Resource of Global Significance. In: Mountains of the World: A Global Priority, B.Messerli and J.D.Ives (Eds.), Parthenon, New York and London. 131-155.

Bätzing, W., 1993. Der sozio-ökonomische Strukturwandel des Alpenraumes im 20. Jahrhundert: eine Analyse von "Entwicklungstypen" auf Gemeinde-Ebene im Kontext der europäischen Tertiarisierung. Geographica Bernensia P26, Department of Geography, University of Berne, Switzerland.

Baumgartner, A., Reichel, E. and Weber, G., 1983. Der Wasserhaushalt der Alpen. Niederschlag, Verdunstung, Abfluss und Gletscherspende im Gesamtgebiet der Alpen im Jahresdurchschnitt für die Normalperiode 1931-1960. Oldenbourg, München, Germany.

Bergström, S., 1995. The HBV model. In: Computer Models of Watershed Hydrology, V.P. Singh (Ed.), Water Resources Publications, Highlands Ranch, Colorado, USA. 443-476.

Browne, T., Fox, R. and Funnell, D., 2004. The invisible mountains. Using GIS to examine the extent of mountain terrain in South Africa. Mt. Res. Dev., 24, 28-34.

CIESIN, Center for International Earth Science Information Network, IFPRI, International Food Policy Research Institute and WRI, World Resources Institute, 2000. Gridded Population of the World $(G P W)$, Version 2. CIESIN, Columbia University, Palisades, NY. Available at http://sedac.ciesin.org/plue/gpw.

CIPRA, International Commission for the Protection of the Alps, 1998. Alpenreport. Daten, Fakten, Probleme, Lösungsansätze. Paul Haupt, Bern, Stuttgart und Wien.

De Martonne, E., 1926. Une nouvelle function climatique. L'indice d'aridité. La Météorologie, 2, 449-459.
Döll, P., Kaspar, F. and Lehner, B., 2003. A global hydrological model for deriving water availability indicators: model tuning and validation. J. Hydrol., 270,105-134.

Dürr, H.H., 2003. Vers une typologie des systèmes fluviaux à l'échelle globale: quelques concepts et exemples à résolution moyenne. Thèse de doctorat, Université de Paris VI, Paris, France.

Falkenmark, M. and Widstrand, C., 1992. Population and water resources - a delicate balance. Pop. Bull., 47, 2-36.

Gleick, P.H., 2002. Water Conflict Chronology. Document available on-line: http://www.worldwater.org/conflict.htm.

GRDC, Global Runoff Data Centre, 2003. Global Runoff Data. Global Runoff Data Centre, D-56068 Koblenz, Germany, http:/ /www.bafg.de/grdc.htm.

Gurtz, J., Zappa, M., Jasper, K., Lang, H., Verbunt, M., Badoux, A. and Vitvar, T., 2003. A comparative study in modelling runoff and its components in two mountainous catchments. Hydrol. Process., 17, 297-311.

Hofer, T., 1998. Floods in Bangladesh: a highland-lowland interaction? Geographica Bernensia G48, Department of Geography, University of Berne, Switzerland.

Imhasly, B., 2003. Hohe Wellen um ein Rinnsal. "Krieg" um Wasser zwischen südindischen Gliedstaaten. Neue Zürcher Zeitung, 08.05.2003, 5 .

Ives, J.D., Messerli, B. and Spiess, E., 1997. Introduction. In: Mountains of the World: A Global Priority, B. Messerli and J.D. Ives (Eds.), Parthenon, New York and London, 1-15.

IPCC, Intergovernmental Panel on Climate Change, 2001. Climate Change 2001 - The Scientific Basis. Contribution of Working Group I to the Third Assessment Report of the Intergovernmental Panel on Climate Change (IPCC), J.T. Houghton et al. (Eds.), Cambridge University Press, UK.

Kapos, V., Rhind, J., Edwards, N., Price, M.F. and Ravilious, C., 2000. Developing a map of the world's mountain forests. In: Forests in Sustainable Mountain Development: a State of Knowledge Report for 2000, M.F. Price and N. Butt (Eds.), IUFRO research series 5. CAB International, Wallingford, UK. 4-9.

Kreutzmann, H., 1998. Wasser aus Hochasien. Konflikte und Strategien der Ressourcennutzung im Pakistanischen Punjab. Geographische Rundschau, 50, 407-413.

Lakshmi, V., 2004. The role of satellite remote sensing in the prediction of ungauged basins. Hydrol. Process., 18, 1029-1034.

Liebscher H.-J., 2004. Potenzielle und aktuelle Wasserkonflikte in grenzüberschreitenden Flussgebieten. Hydrol. Wasserbewirtschaftung, 48, 71-79.

Liniger, H.-P., Weingartner, R. and Grosjean, M., 1998. Mountains of the World: Water Towers for the $21^{\text {st }}$ Century - A Contribution to Global Freshwater Management. Mountain Agenda, Department of Geography, University of Berne, Switzerland.

Malik, M.H. and Khan, M.S., 1998. Hazards of erosion and its effects on the water resources of Pakistan. Ecohydrology of High Mountain Areas., Proc. Int. Conf. Ecohydrology of High Mountain Areas, Kathmandu, Nepal, March 24-28,1996. ICIMOD, Kathmandu, Nepal. 505-518.

Masud, B., 2001. Flash Floods on the Indus River in Pakistan. ICIMOD-Newsletter, 38,13-14.

Messerli, B. and Hofer, T., 2003. Von der Welt der Berner Alpen zu den Gebirgen der Welt. In: Welt der Alpen - Gebirge der Welt-Ressource, Akteure, Perspektiven, F. Jeanneret, D. WastlWalter, U. Wiesmann and M. Schwyn (Eds.), Haupt Verlag, Bern, Stuttgart und Wien, Austria. 9-21.

Messerli, B., Viviroli, D. and Weingartner, R., 2004. Mountains of the world - vulnerable water towers for the $21^{\text {st }}$ century. Royal Colloquium on Mountain Areas: A global resource. AMBIO Special Report 13, 29-34. 
Merz, J., Nakarmi, G. and Weingartner, R., 2003. Potential solutions to water scarcity in the rural watersheds of Nepal's middle mountains. Mt. Res. Dev., 23, 14-18.

Meybeck, M., Green, P. and Vörösmarty, C.J., 2001. A new typology for mountains and other relief classes: an application to global continental water resources and population distribution. Mt. Res. Dev., 21, 34-45.

New, M., Hulme, M. and Jones, P.D., 2000. Global monthly climatology for the twentieth century. Data set available online: http://ipcc-ddc.cru.uea.ac.uk.

Nijssen, B., O'Donnell, G.M., Hamlet, A.F. and Lettenmaier, D.P., 2001. Hydrologic sensitivity of global rivers to climate change. Climatic Change, 50, 143-175.

Nikkanen, R., Wisser, D. and Schumann, A., 2004. Application of water management indicators on different spatial and temporal scales. Hydrol. Wasserbewirtschaftung, 48, 22-27.

Penck, A., 1910. Versuch einer Klimaklassifikation auf physiogeographischer Grundlage. Sitz. Ber. d. Preuß. Akad. Wiss., 12, 236-246.

Price, M.F., Lysenko, I. and Gloersen E., 2004. La délimitation des montagnes européennes / Delineating Europe's mountains. La revue de géographie alpine / J.Alpine Res., 92, 61-86.

Schädler, B., 1985. Der Wasserhaushalt der Schweiz. Mitteilungen der Landeshydrologie, 6. Landeshydrologie, Bern, Switzerland.

Schädler, B. and Weingartner, R., 2002. Components of the natural water balance 1961-1990. In: Hydrological Atlas of Switzerland. R. Weingartner and M. Spreafico (Eds.), Plate 6.3. Federal Office for Water and Geology, Berne, Switzerland.

Schulze, K. and Döll, P., 2004. Neue Ansätze zur Schneeakkumulation und -schmelze im globalen Wassermodell WaterGAP. In: 7. Workshop zur grossskaligen Modellierung in der Hydrologie, R. Ludwig, D. Reichert and W. Mauser (Eds.), Kassel University Press, Kassel.

Schwarb, M., Frei, C., Schär, C. and Daly, C., 2001. Mean annual precipitation in the European alpine region 1971-1990. In: Hydrological Atlas of Switzerland, R. Weingartner and M. Spreafico (Eds.), Plate 2.6. Swiss National Hydrological Survey, Berne, Switzerland.

Siebert, S., Döll, P. and Hoogeveen, J., 2002. Global map of irrigated areas. FAO, Rome, Italy.

Shrestha, M.L., Thapa, K.B., Shrestha, B.R., Bajracharya, B. and Chalise, S.R., 1996. Climatic and Hydrological Atlas of Nepal. ICIMOD, Kathmandu, Nepal.

Spiess, E. (Ed.), 1994. Schweizer Weltatlas. Staatlicher Lehrmittelverlag des Kantons Bern.
Strässer, M., 1998. Diagramme zur Köppenschen Klimaklassifikation. Klett-Perthes, Gotha.

Vischer, D., 1994. Nachhaltige Gewässernutzung am Beispiel der überregionalen Wasserversorgung - Überlebensfrage oder Sehnsucht nach dem Paradies? In: Nachhaltige Naturnutzung. Geographica Bernensia P30, Department of Geography, University of Berne, Switzerland. 21-34.

Viviroli, D., 2001. Zur hydrologischen Bedeutung der Gebirge. Publikationen Gewässerkunde 265. Department of Geography, University of Berne, Switzerland.

Viviroli, D. and Weingartner, R., 2004. The hydrological significance of the European Alps. In: Hydrological Atlas of Switzerland, R. Weingartner and M. Spreafico (Eds.), Plate 6.4. Federal Office for Water and Geology, Berne, Switzerland.

Viviroli, D., Weingartner, R. and Messerli, B., 2003. Assessing the hydrological significance of the world's mountains. Mt. Res. Dev., 23, 32-40.

Vörösmarty, C.J., Green, P., Salisbury, J. and Lammers, R.B., 2000. Global Water Resources: Vulnerability from Climate Change and Population Growth. Science, 289, 284-288.

Vörösmarty, C.J., Sharma, K.P., Fekete, B.M., Copeland, A.H., Holden, J., Marble, J. and Lough, J.A., 1997. The storage and aging of continental runoff in large reservoir systems of the world. $A M B I O, \mathbf{2 6}, 210-219$.

Weingartner, R. and Aschwanden, H., 1992. Discharge regime the basis for the estimation of average flows. In: Hydrological Atlas of Switzerland, R. Weingartner and M. Spreafico (Eds.), Plate 5.2. Swiss National Hydrological and Geological Survey, Berne, Switzerland.

World Bank, 2001. World Development Indicators. International Bank for Reconstruction and Development, Washington D.C., USA. 142-145.

Yang, H. and Zehnder, A.J.B., 2002. Water scarcity and food import: a case study for southern Mediterranean countries. World Dev., 30, 1413-1430.

Zehnder, A.J.B., 1999. Wassernutzung und Nahrungsmittelproduktion - eine internationale Arbeitsteilung? EAWAG news, 46, 18-20.

Zehnder, A.J.B., 2002. Wasserressourcen und Bevölkerungsentwicklung. In: Wasser - essentielle Ressource und Lebensraum, B.Parthier (Ed.), Vorträge anlässlich der Leopoldina-Jahresversammlung vom 6. bis 9. April 2001 in Halle (Saale). Nova Acta Leopoldina, 85, 399-418.

ZVBWV, Zweckverband Bodensee-Wasserversorgung, 2002. Geschäftsbericht 2002. Stuttgart, Germany. 